\title{
Słońce i cień. Dramaturgia Posłańca: Hartley / Pinter / Losey
}

Images vol. XVI/no. 25 Poznań 2015 ISSN 1731-450X
Scenariusz filmu Posłaniec (The Go-Between, 1971) Josepha Loseya powstał na podstawie wydanej w 1953 roku powieści Lesliego Polesa Hartleya. Posłaniec był trzecim wspólnym projektem Harolda Pintera i Loseya, po Stużacym (The Servant, 1963) i Wypadku (Accident, 1967). Za każdym razem Pinter adaptował współczesne powieści: Słu$\dot{z} a c y$ to adaptacja utworu Robina Maughama, Wypadek - Nicholasa Mosleya. Jednak wyłącznie w przypadku Posłańca mamy do czynienia $\mathrm{z}$ pracą nad arcydziełem.

W analizowaniu dramaturgii filmowej, bezpośrednio związanej $\mathrm{z}$ procesem transferu utworu literackiego, trudno pominąć zabiegi adaptacyjne - rozróżnienie pomiędzy adaptacją i dramaturgią wydaje się tu niemal niemożliwe[1]. Tym bardziej, że scenariusz jest dopiero początkiem tworzenia dzieła filmowego - reżyser podejmuje decyzje, które niekiedy modyfikują pierwotny zamysł scenarzysty. Te ogólne uwagi, które można uznać za dość oczywiste i niewymagające formułowania, są jednak w tym przypadku niezbędne. W omówieniu Posłańca trzeba bowiem wyznaczyć trzy poziomy dramaturgii, które ostatecznie budują dzieło filmowe: powieść, scenariusz i zabiegi adaptacyjne, jakich dokonał na nim reżyser.

Kluczowe dla dramaturgii Posłańca - powieści, scenariusza i filmu - wydają mi się decyzje twórców co do ról, jakie wyznaczają nadawcy i odbiorcy. Lub inaczej: jakie napięcia mają rodzić się pomiędzy narratorem (we wszystkich trzech wariantach silnie zaznaczonym) a czytelnikiem/widzem. Co za tym idzie, istotne są też zabiegi subiektywizujące narrację, a więc poddające pod osąd odbiorcy konstrukcję świata przedstawionego, jego wiarygodność. W powieści, scenariuszu i filmie niezwykle ważne okazują się gry z czasem opowiadania wraz z konsekwencjami, jakie płyną z nich dla kreślenia postaci i ich oceny. W dziele filmowym Loseya - będącym wariantem zarówno powieści Hartleya, jak i scenariusza Pintera - kluczowa jest metoda budowania semantyki kadru. Dla widza ona właśnie stanowi zwieńczenie zamysłu scenarzysty.

Pierwsze zdanie powieści L.P. Hartleya brzmi: „Przeszłość to odległa kraina, wszystkie jej wydarzenia mają inne wymiary”"[2]. Owe inne wymiary zdają się wskazaniem subiektywizacji narracji, jej skupienia na
"Jasne i ciemne plamy"
[1] Pisząc o dramaturgii, pojęcie to rozumiem nie tylko jako sposób prowadzenia akcji, jej logikę i przejrzystość, ale również jako wybór modelu narracji i strategii porozumienia $\mathrm{z}$ odbiorcą.
[2] L.P. Hartley, Posłaniec, przeł. R. Grzybowska, Warszawa 1978, s. 7. Pozostałe cytaty pochodzą z tego wydania powieści. Interpunkcja w cytatach jak w oryginale. 
wspomnieniu, procesie odtwarzania nie tyle faktów, ile emocji z nimi związanych i ich konsekwencji. Narratorem jest mężczyzna „w wieku lat sześćdziesięciu kilku” (s. 7), który po upływie pięćdziesięciu dwóch lat wspomina wydarzenia z lipca 1900 roku - jako trzynastolatek przebywał wówczas na wakacjach w domu szkolnego kolegi. Nie wiemy, co jest impulsem do podjęcia pracy pamięci, odtwarzania traumatycznego doświadczenia, jakie zaważyło na całym życiu bohatera. Gdyby nie ono, „Siedziałbym w innym, tęczowym pokoju i nie patrzyłbym w przeszłość, lecz w przyszłość. I nie byłbym samotny" (s. 9). Może do trudu spisania wspomnień skłania przypadkowe odnalezienie pamiętnika, może chęć rozliczenia się z samym sobą. Hartley wskazuje raczej na drugą przyczynę - Leo Colston wydaje się zdeterminowany, by nie tyle zrozumieć zdarzenie, które zniszczyło jego emocjonalność i zmusiło do izolacji, ale by egzorcyzmować przeszłość, uczynić ją mniej przerażającą i groźną. Narrator Posłańca to mężczyzna świadomy: potrafi nazywać własne lęki i płynące $z$ nich ograniczenia, ale nie jest w stanie ich pokonać. W wewnętrznej walce zwycięża jednak głos małego Leo, zdający się mówić dorosłemu: „Spróbuj teraz, spróbuj, jeszcze nie jest za późno” (s. 23). Trudno nie dostrzec dramatyzmu owego starcia, jego uczestnicy są nazwani aż nazbyt dokładnie: to trzynastolatek i sześćdziesięciopięciolatek, z których tylko ten pierwszy doświadczył życia w jego pełnym wymiarze. Rozpaczliwe wahania bohatera kończy wyznanie na wskroś przejmujące: nikt przez lata nie wypowiadał jego imienia.

Hartley nie tyle jednak subiektywizuje narrację, ile w Prologu wyznacza czytelnikowi istotną rolę: ma on być świadkiem procesu, w jakim bohater rekonstruuje własną tożsamość, a tym samym odzyskuje nadzieję na odrodzenie. Znacząca wydaje się tu metaforyka, przy pomocy której opisuje swój stan (s. 21):

[...] każdy człowiek w pewnych sytuacjach staje się ważny dla samego siebie. Moim celem było pomniejszanie tej ważności i rozłożenie jej jak najcieńszą warstwą na całe półwiecze. Dzięki tej pogrzebowej taktyce pogodziłem się z życiem, zawarłem próbny - oto właściwe słowo - układ stawiając jeden warunek, że nie będzie ekshumacji. Czy to prawda, że najwięcej energii jak czasami sobie mówiłem - poświęciłem sztuce pogrzebowe.

Czytelnik ma zatem być świadkiem owej ekshumacji: „To ja, starszy, stary Leo, dokonuję tego post mortem" (s. 224).

Powieść Hartleya rozpoczyna się Prologiem, w którym Leo Colston odnajduje swój pamiętnik z 1900 roku, a kończy Epilogiem - bohater wraca do Brandham Hall, by dokonać konfrontacji tego, co pozostało w jego pamięci, z miejscem, świadkiem jego traumy. Dwadzieścia trzy rozdziały są dokładnym opisem wydarzeń, jakie miały miejsce podczas niemal trzech tygodni pobytu Leo w posiadłości wynajmowanej przez rodzinę Maudsleyów[3]. A raczej uporczywym odtwarzaniem tego, co Colston pamięta pomimo upływu pięćdziesięciu dwóch lat. To bolesna

[3] O symbolice domu w Posłańcu pisze Urszula Tes. Por. eadem, Joseph Losey. Niebezpieczne gry, w: Auto- rzy kina europejskiego II, red. A. Helman, A. Pitrus, Kraków 2005, s. 176. 
i żmudna praca, bo jak stwierdza na początku: „Pamiętam katastrofę całkiem dobrze, ale nie etapy, które do niej doprowadziły" (s. 12). Po katastrofie, czyli ujrzeniu aktu miłosnego Marian i Teda, kobiety, w której się zakochał, i mężczyzny, któremu zaufał, Leo stracił pamięć. Brutalność tej inicjacji wynikała również z faktu, że był posłańcem nosił sekretne listy umożliwiające potajemne spotkania panny $z$ dworu i dzierżawcy. Misja, którą zrazu wypełniał z radością, z czasem stała się zbyt trudnym obowiązkiem, kochankowie zmuszali więc trzynastolatka do przekazywania informacji, uciekając się do emocjonalnego szantażu.

O wydarzeniach z lata 1900 roku opowiada stary Leo - nie rozstrzygniemy, czy to rekonstrukcja faktów, czy ich istotnego sensu; czy narracja układa się tak płynnie, dlatego że jest właśnie odtwarzaniem stanów i emocji? Hartley wie, że czytelnik może podważać obiektywizm Colstona, tym bardziej że w finale poznamy wersję Marian Maudsley, najważniejszej bohaterki lipcowego dramatu - wersję inną, zakłamaną przez pamięć i chęć usprawiedliwienia własnych czynów. Sposobem na to, byśmy uwierzyli, że historia Leo w najwyższym stopniu odpowiada prawdzie i oddaje rzeczywisty kształt zdarzeń, jest nie tylko wielość szczegółów i wiarygodne przedstawianie emocjonalności dziecka, ale również, paradoksalnie, interwencje, jakich dokonuje stary Colston. $\mathrm{Z}$ perspektywy dorosłego ocenia zdarzenia i ich znaczenie, nazywa uczucia, którym ulegał, ale także rewiduje spojrzenie trzynastolatka na to, co go spotkało. Mówiąc o jednym z epizodów z początku pobytu ubogiego chłopca w zamożnym domu, stwierdza wprost: „Był to rzeczywisty początek powolnego prześladowania - bardzo powolnego" (s. 48).

Powieść Hartleya można czytać również w innym kluczu - niezwykle istotne wydaje się, jak często Leo Colston wspomina, kiedy miała miejsce jego przemiana: „Rok 1900 miał dla mnie prawie że mistyczny urok - wprost nie mogłem się go doczekać” (s. 10). Również w wewnętrznej walce pojawia się motyw roku 1900 - na wspomnienie traumy mężczyzna przekonuje sam siebie: „Ale miałeś połowę wieku, żeby się z tym uporać. Połowę wieku, połowę dwudziestego wieku, tę wspaniałą epokę, ten Złoty Wiek, który ci przekazałem” (s. 22). Gdy Colston wraca do Brandham Hall, stwierdza: „Zmieniła się wieś, tak jak zmieniło się wszystko w ciągu pięćdziesięciu lat - to półwiecze obfitowało w największe zmiany na przestrzeni historii" (s. 306). Posłaniec Hartleya może być opowieścią o zawiedzionej nadziei, żywionej nie tylko przez trzynastoletniego chłopca, który zakochał się po raz pierwszy. Świadectwem niszczenia wszystkiego, co w człowieku najlepsze i najpiękniejsze[4].

Tym, co w równie istotny sposób wyznacza dramaturgię powieści, jest symbolika światła i cienia. Lipiec 1900 roku był wyjątkowo upalny, światło słoneczne - intensywne, jego blask dodawał Leo siły, pocieszał go, poprawiał nastrój („Jakąż miało siłę! [...] Wszystko było

[4] Por. B. Jay, Method and Myth in L.P. Hartley's „The

Go-Between”, „Studies in Literature and Language”

2012, vol. 5, nr 3 . 
dziełem słońca, ale podziałało też na mnie, zmieniło koloryt mych myśli”, s. 125). Bardzo często pojawiają się opisy jasnych pejzaży, również ludzie wyglądają inaczej w pełnym słońcu. Marian nazywa chłopca swoim „jedynym promykiem” (s. 138). Jasność, która towarzyszyła euforii spełnienia jego marzeń o pięknie, znikła wraz z przedwczesną, niechcianą inicjacją. W dniu trzynastych urodzin Leo został siłą zaprowadzony przez matkę Marian do szopy w starym ogrodzie, gdzie spotykali się kochankowie. To pierwszy deszczowy, ponury dzień w Brandham Hall.

O ile lipiec 1900 roku był przepełniony światłem, o tyle kolejne lata okazały się ciemniejsze: „Słońce i cień na zewnątrz, słońce i cień w moich myślach" - napisze stary Leo (s. 140). A jednocześnie minione zdarzenia również zatraciły swój blask, w ich opisie często pojawiają się światłocienie: „Pogrzebane wspomnienia z Brandham Hall zachowały się w mojej pamięci niby efekty światłocieni - jasne i ciemne plamy" (s. 36). Odzyskiwanie pamięci łączy się z odzyskiwaniem jasności widzenia: „Owe początkowe dni to okres zmiennych wrażeń, nie powiązanych ze sobą, niewiele mających sensu. Obrazy tkwią we mnie przeważnie w tonacji jasnej i ciemnej, czasami są zabarwione jakimś kolorem" (s. 42). Wysiłek, jaki podejmuje Leo Colston, by odzyskać zdolność dostrzeżenia kolorów, wydaje się ogromny.

Innym niezwykle istotnym zabiegiem dramaturgicznym, który stosuje Hartley, jest zaburzenie chronologii zdarzeń. W niektórych partiach powieści następują one po sobie jedynie pozornie - $\mathrm{w}$ istocie narrator wprowadza drobne przesunięcia: najpierw relacjonuje wieczór, potem popołudnie. Owo zaburzenie ma miejsce wówczas, gdy Leo jest szczególnie poruszony. Praca pamięci, śledztwo świadomości, które ukazuje Hartley, jest procesem bolesnym. Co więcej, nie wiemy, czy rola posłańca wyznaczona mu ponownie po pięćdziesięciu dwóch latach przez Marian - ma przekonać jej wnuka, że bycie potomkiem Teda (co młodzieniec uważa za wstydliwe), a nie jej prawowitego męża, nie pozbawia go prawa do spełnienia w miłości - okaże się wyzwoleniem z udręki przeszłości.

„Podwójna rama”

Harold Pinter w scenariuszu Posłańca dokonał kilku istotnych zmian wobec powieści Hartleya. Przede wszystkim bezpośrednio nie wspomina o czasie akcji (jedynie w opisie maszyn rolniczych, które określa jako „pochodzące z 1900 roku”[5]), ale rozpisuje ją na przeszłość, teraźniejszość i czas neutralny (time neutral)[6]. O ile dwa pierwsze określenia wydają się jasne, o tyle ostatnie okazuje się tajemnicze i jednocześnie kluczowe. Ów czas to czas zatrzymany, moment przesilenia: Leo zostaje zmuszony przez panią Maudsley, matkę Marian, do wyjawienia miejsca pobytu dziewczyny owego feralnego wieczoru, gdy

[5] H. Pinter, The Go-Between, w: idem, Five Screenplays, London 1971, s. 287. Pozostałe cytaty - w moim tłumaczeniu - pochodzą z tego wydania.

[6] Joseph Losey planował realizację adaptacji W poszukiwaniu straconego czasu Marcela Prousta.
O związkach Posłańca z tym projektem zob. np. E.T. Jones, Summer of 1900: A la Récherche of the Go-Between, „Literature/Film Quarterly” 1973, vol. 1, nr 2. 
odkryto romans z dzierżawcą, a potem siedzi w umywalni. To chwila, w której czas stanie w miejscu na pięćdziesiąt dwa lata. Pinter zapisuje ją oszczędnie i przejmująco: pani Maudsley i Leo stoją w ogrodzie, potem Leo jest już sam, w odosobnieniu, a z offu pada pytanie kobiety: „Do kogo je [listy - przyp. O.K.] zanosiłeś?”. W następnej scenie, w porządku teraźniejszości, Colston na ulicy we wsi spotyka młodego człowieka możemy się domyślać, że to wnuk Marian i Teda.

Jeśli chodzi o ,innych” z Brandham Hall, to jakoś nie mogłem sobie wyobrazić, że działo się z nimi coś dalej, gdy ja się zatrzymałem. Byli niczym postacie na obrazie, otaczała ich rama, podwójna rama czasu i miejsca, nie mogli poza nią wykroczyć, zostali uwięzieni w Brandham Hall, latem roku 1900. Niechaj tam pozostaną, zamknięci w tych dwóch wymiarach. Nie miałem ochoty ich uwolnić.

- stwierdza powieściowy Leo Colston (s. 304). W scenariuszu Pintera, który rozpoczyna się - tak jak dzieło Hartleya - zdaniem o przeszłości jako obcej krainie, słowa te wypowiada $\mathrm{z}$ offu stary Colston, podczas gdy na ekranie ma być widoczny pejzaż angielskiej wsi. Główny bohater jest nazywany Leo (trzynastolatek) i Colston (starszy mężczyzna, po latach wracający do Brandham Hall).

Pinter nie wprowadza narratora tak, jak czyni to Hartley. Po pierwszym zdaniu, sugerującym, że zdarzenia, jakie zostaną przedstawione, są wspomnieniem, postać narratora znika na dość długo. Wrażenie, że chłopiec przybywający do wiejskiej posiadłości może być tym, który po latach opowiada tę historię, pozostaje mgliste.

Przeszłość jest jednak zaburzana pojawianiem się mężczyzny. Pinter przekłada Hartleyowskie interwencje na obrazy: pojawia się w nich Colston przybywający do Norwich, a stamtąd do Brandham Hall. Owych wtargnięć teraźniejszości jest w scenariuszu siedemnaście, jako osiemnasta pojawia się finałowa rozmowa Marian i Colstona - stara kobieta prosi dawnego posłańca, by podjął się ostatniej misji.

Niezmiernie istotne wydają się dwie kwestie: status owego mężczyzny, określanego w scenariuszu jako Colston, i przyczyna jego pojawienia się w Brandham Hall. Jak wspominałam, Pinter rezygnuje z rozbudowanego wprowadzenia, jakie czyni Hartley - pozostawia jedynie pierwsze zdanie powieści, w tym kontekście brzmi ono niepokojąco. Gdyby nie nazwanie postaci, nie znalibyśmy jej tożsamości - dla widza filmowego, nie znającego tekstu scenariusza, długo pozostaje ona niejasna. Nie wie, kim jest mężczyzna, którego głos słyszy, widząc kilkunastoletniego chłopca podczas podróży do wiejskiej posiadłości i w wyprawie z Marian do Norwich (wówczas z offu pada zdanie: „Podleciałaś zbyt blisko słońca i wypaliłaś się”, s. 295). Tym bardziej że Pinter - co bardzo znamienne - zaburza porządek chronologiczny wizyty: najpierw pokazuje Colstona we wsi, potem przybywającego do Norwich, najpierw oglądającego bibeloty w pokoju domku, jaki zamieszkuje pod koniec życia Marian, potem wchodzącego do tegoż et cetera. Pojawianie się mężczyzny staje się coraz bardziej złowieszcze, a jednocześnie pozostaje w zgodzie z prozą Hartleya. Fragmentem, 
który w powieści wydaje się najbardziej niepokojący, jest opis okolic rzeki: „Przed nami majaczyło się coś czarnego, jakieś barierki, paliki i stojaki, przypominające szubienicę. Wprowadzało to atmosferę grozy i całkowitego osamotnienia. Wydawało się, że jest to coś, do czego nie należy się zbliżać, że może człowieka złapać i wyrządzić mu krzywdę" (s. 62). W scenariuszu Pintera ową grozę potęguje nie pejzaż czy zachowanie postaci, ale właśnie owo nieoczekiwane zaburzenie porządku czasowego, pomieszanie przeszłości i teraźniejszości (i jej chronologii, o czym wspominałam), zwłaszcza że wydarzenia minione w istocie nie są wprowadzane jako retrospekcje, ale dominują, organizują świat przedstawiony niemal w całym filmie[7].

Owa rozdzielność postaci Leo i Colstona zdaje się wyprowadzona z dzieła Hartleya: trauma z dzieciństwa sprawiła, że integralność postaci uległa rozbiciu. Colston, wspominając podarunek, jaki otrzymał - zielone letnie ubranie, stwierdza: „Czuję sie tak, jakbym był zupełnie kimś innym” (s. 57). Nieco później: „Może niezbyt jasno, ale zdawałem sobie sprawę, że ona [Marian - przyp. O.K.] jest skałą, w zetknięciu z którą pękłem na pół” (s. 251). Przybywając po latach do Brandham Hall, bohater zauważa ze zdziwieniem, że wszystko, co zapamiętał, ma inne proporcje: „Kąt widzenia zmienia obraz” (s. 305). W scenariuszu Pintera nieprzystawalność Leo i Colstona zdaje się wynikać nie tylko z prostej organizacji świata przedstawionego filmu, w którym dziecko i dorosłego grają różni aktorzy - życie Leo rozpadło się na dwoje, dziecko i dorosły to dwie różne osoby. Przywrócenie ciągłości ludzkiego losu, jeśli w ogóle jest możliwe, wymaga ogromnego wysiłku. Według scenariusza twarz Colstona ma być pokazana dopiero pod koniec, w czternastej scenie z teraźniejszości.

Pinter wyraźnie sugeruje, że Colston nie powrócił do Norfolk z własnej woli - został wezwany przez Marian. Ma wypełnić kolejną misję - w ostatniej scenie przyjeżdża do Brandham Hall, by porozmawiać z jej wnukiem. Na dworcu w Norwich wsiada do samochodu $\mathrm{z}$ kierowcą. Potem przybywa do wsi i do domu kobiety. W scenariuszu Colston jest postacią dużo bardziej bierną niż w powieści. Tą, która decyduje o jego życiu, jest Marian.

Jedna $\mathrm{z}$ pierwszych kwestii, jakie padają $\mathrm{w}$ filmie, to pytanie o Leo, formułowane przez gościa bawiącego w ogrodzie Maudsleyów: „Kto to jest?”. Chłopiec nie przynależy do świata, do którego przybywa, jest w nim obcy. Kolejne słowa wypowiada Marcus, brat Marian: „Moja siostra jest bardzo piękna”. „Tak” - odpowiada Leo. Następna scena rozgrywa się w ogrodzie, gdzie chłopcy znajdują krzew wilczej jagody. Leo wymienia jej nazwę: „Atropa belladonna”. Marcus pyta: „Atropa jaka?”. Pada odpowiedź: „Atropa belladonna. Jest trująca. Każda jej część jest trująca”. W powieści Hartleya Marcus i Leo również znajdują wilczą jagodę, jej opis wydaje się znaczący: „Wyglądała niczym obraz

[7] Rzecz jasna, w porządku filmowej narracji można je traktować jako retrospekcje narratora - dorosłego Leo Colstona. Interpretacja taka jest możliwa dopiero na poziomie dzieła filmowego - wobec scenariusza stanowiłaby nadużycie. 
uosabiający zło, ale także i zdrowie - była wspaniała, mocna i soczysta" (s. 43). W wersji Pintera bezpośredniość tych scen jest jednak dużo dobitniejsza i stanowi wyraźną wskazówkę: Marian okaże się dla Leo trucizną, przyniesie śmierć.

Scenariusz Pintera opiera się zatem na dwóch założeniach dramaturgicznych: pierwsze z nich, pozornie oczywiste, polega na rozbiciu postaci Leo Colstona. Rozbiciu na tyle silnym, że odbiorca nie postrzega dziecka i dorosłego jako jednej osoby. Drugie, wynikające po części z pierwszego, to wprowadzanie zaburzeń narracyjnych w postaci scen $\mathrm{z}$ teraźniejszości. Co więcej, dorosły Leo Colston, w przeciwieństwie do powieściowego, jest w nich niemal pozbawiony głosu: kilkakrotnie komentuje zza kadru zdarzenia, a w scenie rozmowy z Marian wypowiada jedynie pojedyncze kwestie - to kobieta okazuje się silna i dominująca.

Joseph Losey, realizując Posłańca, wprowadził do scenariusza kilka istotnych zmian. Najważniejszą wydaje się usunięcie wszystkich scen, w których nie występuje Leo - tym samym świat przedstawiony oglądamy jedynie za pośrednictwem bohatera. Pozornie nieznaczące epizody, mające pozostać tłem dramatu, zostały pominięte - w filmie Loseya niemożliwe jest spojrzenie na zdarzenia lata 1900 roku z perspektywy innej niż określona przez Leo. A jednocześnie Losey rezygnuje z kilku fragmentów z teraźniejszości zaprojektowanych przez Pintera lub umieszcza je w innym miejscu. Usuwa również niektóre wypowiedzi Marian z teraźniejszości, tym samym przesuwając znaczenie na obraz. Rozpatrując dramaturgię filmu Loseya, najistotniejsze wydają się właśnie zabiegi dotyczące kompozycji kadrów i wprowadzania kolejnych sekwencji oraz sposób, w jaki reżyser pokazuje postać narratora - dorosłego Leo Colstona (Michael Redgrave).

Tym, co niezmiennie zachwyca i uwodzi w filmie Loseya, jest uroda kadrów: pejzaże angielskiej wsi (Posłaniec był kręcony w Norfolk) są komponowane niczym malarskie płótna, a jednocześnie obciążone znaczeniem. Niekiedy w pojedynczych ujęciach zawiera się zapowiedź zdarzeń i ich konsekwencji. Kiedy Leo po raz pierwszy spogląda z okna posiadłości Maudsleyów na ogród, widzi scenę gry w krykieta: to właśnie gra - towarzyska i międzyludzka - okaże się kluczowa w dramacie chłopca. Przekroczenie jej reguł stanie się przyczyną śmierci Teda i traumy Colstona. Tym samym Losey zwraca uwagę na temat społecznego porządku: przynależność do określonej klasy determinuje ludzki los, próba zmiany miejsca w hierarchii kończy się tragicznie. Leo patrzy przez okno z ciekawością - widz zauważa, że chłopiec znalazł się w otoczeniu sobie nieznanym, owo ujęcie wskazuje na jego odmienność. Padające w scenariuszu Pintera pytanie „kto to jest?” jedynie dopełnia obrazu inności, nieprzystawalności Leo do tego świata. Kolejne ujęcie leżącej na hamaku pięknej Marian wyznacza następny trop interpretacyjny.

Tym, co wyraźnie określa świat przedstawiony filmu, jest opozycja światła i cienia. Fragmenty teraźniejszości są wyraźnie niedoświet- 
lone, Colston przybywa do krainy dzieciństwa wiosną lub jesienią, gdy światło słoneczne nie jest intensywne - kadry są szare, jak gdyby niebo spowijała gęsta warstwa chmur, zaczyna padać deszcz (krople rzęsistego deszczu towarzyszą również czołówce filmu). W scenie rozmowy z Marian, w pokoju małego domku, który ta zamieszkuje, mrok się pogłębia, mimo że bohaterowie siedzą przy oknie. Tutaj po raz pierwszy widzimy twarz Colstona w zbliżeniu - dotąd oglądaliśmy ją z pewnej odległości, postać kadrowano w planach ogólnych, choć twarz mężczyzny (wbrew intencji Pintera) była wyraźna.

Opozycja jasne-ciemne staje się kluczowa w dramaturgii filmu. Wydarzenia lata 1900 roku są przeniknięte słońcem, niektóre kadry wydają się zbyt rozświetlone - odbiorca ulega wrażeniu, że powinien zmrużyć oczy, by dostrzec to, co zostało ukazane na ekranie. Kontrast mroku teraźniejszości i niemal ekstatycznego lśnienia przeszłości załamuje się w scenie odkrycia związku Marian i Teda - ulewny deszcz sprawia, że zaczyna dominować szarość. Tak jakby krystaliczność świata załamała się w chwili, gdy został wydany wyrok na Teda (który zaraz po tym incydencie popełnił samobójstwo) i Leo.

W dramaturgii Posłańca Loseya odnajdujemy jeszcze jeden niezwykle istotny element: obsadzenie w roli Colstona Michaela Redgrave’a i jego sposób budowania postaci. Colston, w scenariuszu i filmie niemal pozbawiony głosu, w kreacji Redgrave’a jest człowiekiem zniszczonym, wypalonym, jak u Hartleya - „spopielałą istotą” (s. 22). Ubrany w szary garnitur, nieco zgarbiony, wydaje się dużo starszy niż w rzeczywistości. Najbardziej przejmujące okazuje się jednak spojrzenie Colstona - to spojrzenie przestraszonego, zdezorientowanego dziecka. Bohater Redgrave’a w istocie „zatrzymał się,, jego emocjonalność uległa regresowi. Gdy Marian mówi mu, że powinien się ożenić, że jest „wyschnięty od środka”, na twarzy mężczyzny maluje się dziecięce niemal zawstydzenie. W ostatniej scenie filmu, gdy z tylnego siedzenia samochodu obserwuje dwór, dokąd ma udać się z misją wyjawienia wnukowi Marian prawdy o miłości babki, z obawą spogląda przez mokre od deszczu szyby. Jest niczym mały Leo, nie chce już wypełniać poleceń dorosłych. Losey buduje tym samym klamrę kompozycyjną: deszcz w czołówce jest tym samym, który pada podczas powrotu Colstona do Brandham Hall. W podwójnej ramie - czasu i miejsca - zostaje uwięziony również Leo. Pozostaje mu kolejna niechciana rola: już nie posłańca, ale tego, kto opowiada własną historię. 